\title{
Violent societies: Educating the upcoming generations about their social contract
}

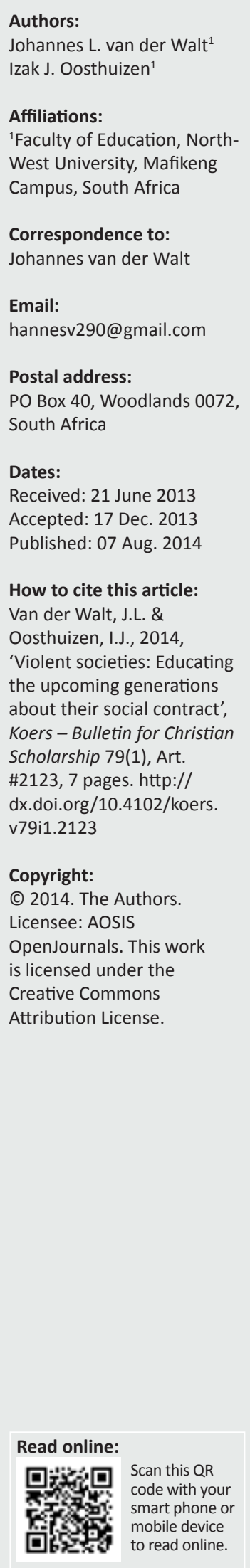

The citizens of many countries in the world, particularly of South Africa, are experiencing the collapse of the social order in their country as a result of certain circumstances. This fact of social disintegration has led educationists to again examine the nature and contents of the social contract that the South African citizenry has entered into. In secular states, the social contract should at least be rooted in two ethical principles, namely trust and humanistic versions of the Golden Rule. Analysis of the South African social contract demonstrates this point, and also shows how a positive modus vivendi [living together] can flow from the recognition and application of these two principles. The upcoming generations should therefore be educated to understand the nature and content of their social contract, the two ethical principles, and the need for a positive modus vivendi based on their particular social contract.

Gewelddadige samelewings: Die opvoeding van die opkomende geslagte rakende hulle sosialekontrak. Dieburgersvanbaielandeindiewêreld, dogindiebesonderdiévanSuid-Afrika, ervaar tans dieineenstorting van die sosialeordein hulleland as gevolg van dieinspeling van baie faktore. Hierdie toestand van sosiale disintegrasie het opvoeders en opvoedkundiges daartoe gelei om andermaal die aard en die inhoud van die sosiale kontrak waartoe Suid-Afrikaners hulle verbind het, te ondersoek. Die sosiale kontrak behoort in sekulêre state minstens in twee etiese beginsels gewortel te wees, naamlik vertroue en humanistiese weergawes van die Goue Reël. ' $n$ Ontleding van die Suid-Afrikaanse sosiale kontrak illustreer hierdie punt, en toon ook hoedat ' $n$ positiewe modus vivendi [saamlewe] kan voortvloei uit die erkenning en toepassing van hierdie twee beginsels. Die komende geslagte behoort derhalwe opgevoed te word om die aard en inhoud van hulle sosiale kontrak, die twee etiese beginsels waarop dit behoort te berus, en die noodsaaklikheid van 'n positiewe modus vivendi te verstaan en toe te pas.

\section{The need for societies to revisit their social contracts}

The Republic of Georgia has recently (2013) launched an advertising campaign on South African radio in which it attempted to entice South Africans to emigrate to Georgia (Radiosondergrense [RSG] 2013; also cf. Prasad 2012). The advertisements capitalised on the dangers of living in South Africa by mentioning that around 16000 people had lost their lives in 2012 due to violence, including brutal farm murders and assaults. Whilst this campaign seems to have been opportunistic, it cannot be denied that South Africa has become one of the most violent societies in the world. A large number of people are killed per annum and many women and children suffer rape and sexual abuse. The population also suffers from alleged police brutality, as evidenced by the Marikana massacre, the death of Andries Tatane near Ficksburg and the incidents in 2013 where police officers dragged crime suspects behind police vehicles (see Mail E Guardian 2013).

A perusal of only two newspapers published on Wednesday 27 March 2013 revealed the following atrocities that seem to demonstrate the hazardous nature of living in South Africa: the rape, mutilation and killing of a 14-year-old, atrocities in the name of Satanism, corruption, police brutality, the story of men who do not father their children (see The Star 2013:4-5, 8), the police minister to pay damages, rape, brutality the result of entitlement, and the rise of religious intolerance (see The Citizen 2013:6, 12-13). According to the Institute for Security Studies (ISS), commercial farmers in South Africa are in greater danger of being killed than the police: 91.8 per 100000 of the population as against the police's 51.0 per 100000 (RSG 27 March 2013).

Whilst this brief description seems to provide evidence of an unsafe situation in South Africa, it should not be thought that other countries are much safer. As will be shown, developed societies such as those of the United States of America and Norway have recently similarly suffered from anti-social behaviour. The situation in South Africa is not unique, but serves as inspiration for educationalists to examine the problem and to search for a solution. 
The above seems to suggest that social cohesion has increasingly deteriorated because of a lack of understanding of what a social contract amongst citizens entails. Young people of the early 21st century seem to be growing up under the mistaken impression that each of us has to only look after him- or herself. Each individual has to cope as best as possible in the social 'jungle out there', and this has resulted in an escalation of anti-social behaviour. The situation has been exacerbated by the advent of the postmodern zeitgeist characterised by, inter alia, a feeling of alienation and social collapse (Wilber 2000:12).

The current postmodern attitude of value relativism has most likely made a contribution to this selfish and self-centred attitude. According to Parkin (2011:154-155), people have a supermarket of values at their disposal, and its impact on the inner self of disorganised and vulnerable individuals ${ }^{1}$ has become the criterion for choosing values (De Botton 2012:95). According to Bower (2005:181, 254), it is a tenet of the postmodern perspective that people create personal meaning in regard to their identity, value and purpose. McGrath (2005:218) concurs: reacting to the simplistic statements of the Enlightenment, postmodernity has stressed the limits to human knowledge and encouraged a toleration of those who diverge from the 'one size fits all' philosophy of modernity. The world in which we live is seen as a place where nothing is certain, guaranteed or unquestionably given. It has become fashionable, Needleman (2008:61) contends, to deny the existence of absolutes in the ethical sphere. All morality is seen as relative to time, place, ethnicity, religion, social class, nationality and so on. The postmodern zeitgeist, says Needleman (2008:108), dispirits people with ethical cynicism and relativism. It reduces every viewpoint, every norm and conviction, however firmly believed by some, to a temporary phenomenon, an event of a transient nature. Everything is seen as historically determined and historically relative, in other words, everything is relativised (Van der Walt 2007:178).

According to Olthuis (2012), some people demand that we move beyond life view exclusivism into an era beyond concern with world views. Life is seen as more than logic; there is a limit to knowledge; knowledge is never disinterested, neutral, a-temporal or a-spatial. According to Wright (2010:122), some postmodernists even claim that ultimately we fail to obtain knowledge of reality because, at the end of the day, there is no such thing as reality, no actual order of things. The notion of reality exists only within our psychological conventions and linguistic contractions. ${ }^{2}$

\section{Our contention}

A possible solution to the problem of social and value disintegration due to political disruption and possibly also

1.South Africans' disorganisation and vulnerability have been compounded by their recent history: their struggle against apartheid has in many cases been characterised by lawlessness and anarchy; the post-apartheid regime has now been struggling for two decades to find its feet and to steady the political and social boat.

2.According to Wright (2010:123), these thinkers fall in the epistemic fallacy of confusing reality with knowledge of reality. We have no grounds to deny the existence of reality simply because it is beyond our intellectual powers to fully comprehend it. the postmodern spirit of the times is to pertinently educate the upcoming generations about the nature of the social contract into which they as citizens of the country have entered because of living in the territory of an independent state with a legitimate government and a particular social order. This contention will be defended by drawing attention to the following facets of the problem: a brief outline of the concept 'social contract'; a discussion of the tolerance of others and their differences; the nature of the social contract specifically in South Africa, and of the educational imperatives flowing from these outlines and discussions.

\section{Social contract: Theoretical perspective}

The earliest proponents of the social contract, Socrates and Plato, sought to provide a rational perspective of what is necessary to achieve a state which the members of a society can depend upon to living well. Originally conceived as a normative theory of moral and political obligations determined by an understood contract and incumbent upon members of a society, this theory has been debated over the centuries since (cf. Columbia Electronic Encyclopedia n.d.:1-1). Nonetheless, as Byerly (2013:5) has noted, it endures and, for more modern purposes, has been extended to include not only society and government, but also business. Its basic premise is still the same: to understand and determine what roles, relationships and responsibilities each citizen has relative to the whole of society and its collective well-being.

Thomas Hobbes (in the Leviathan 1651) and John Locke first actually formulated it as a formal theory by which people are said to have abandoned the 'state of nature' to form a more organised and just society. They assumed that people at first lived in a state where there was no organisation or government. Hobbes maintained that by the social contract people had surrendered their natural liberties in order to enjoy the order and safety of the organised state, whereas Locke made the social contract the basis of his advocacy of popular sovereignty, the idea that the government must reflect the will of the people.

Like Locke, Jean Jacques Rousseau, in Le contrat social (1762), found in the general will a means of establishing reciprocal rights and duties, privileges and responsibilities as the basis of a state. Similar ideas were used as a justification for both the American and the French revolutions in the 18th century. Thomas Jefferson, for instance, held that the preservation of certain natural rights was an essential part of the social contract; consent of the governed was fundamental to any exercise of governmental power.

In brief, the social contract is the hypothesis that human beings, as they came together to live in communities and society, thus encountering interdependencies, must reach a common agreement regarding the relationships and responsibilities and rights of that society's members. It represents an implied contract, agreement or covenant by which individuals are said to have abandoned their 'natural state' and its freedoms to form the more organised society in which they now live (Byerly 2013:6). 
Peaceful coexistence (a positive modus vivendi) and tolerance in a community or a society depend on a social contract amongst the members of such a community. The contract therefore should provide room for diverse positions in society; it emerges from a joint decision of rational individuals. Antecedent to a social contract there are no principles of justice or agreement about expectations in force. Put differently, the emergence of a social contract amongst individuals who widely differ from one another in terms of background, religion, culture, customs and habits leads to a well-ordered society, to the well-being of all the contracting parties and to social justice for all concerned (Strauss 2009:510-511). Following Rousseau, Rawls (2007:566-571) states that government is based on a social contract amongst free, equal and rational persons entering into a contract based on the principle of justice as fairness and for the wellbeing of all concerned. The contract leads to the adoption of certain rights and duties and to the measuring out of benefits for everyone.

Bower's (2005) assessment of the Constitution of the United States of America gives an idea of what a social contract could mean for all. That Constitution:

is nothing if not a repository of human values [which] had a profoundly beneficial effect on the development of civil society, on the emergence of a trustworthy judiciary and on the achievement of freedom .... (pp. 226, 228)

Part of the social contract is also common law which, in his opinion, governs the affairs and relationships of people. Nussbaum (2000:5) adds to this that all governments should adhere to those principles that a minimum of respect for human dignity requires. The contract should therefore provide for treating each person as an end and none as a tool of others. According to Robeyns (2005:passim), the capabilities approach worked out by Nussbaum and Sen forms a broad normative framework for what has been referred to above as a social contract. Sen $(2010: 245,247)$ concurs by saying that it would be hard to understand why and how a person undertakes some of his or her activities without comprehension of his or her societal relations. Individual human beings, with their various plural identities, multiple applications and diverse associations, are quintessentially social creatures with different types of societal interaction.

\section{Tolerance as upshot of the social contract}

After having looked at the nature and purpose of the social contract amongst individuals, we can now turn to the issue of tolerance in an educational context. The question is, who would be most willing and ready to enter into a social contract with others and hence be more tolerant of others and their views? To ask this question is more of an academic exercise than of practical significance since all of us, whether we wish to do so or not, are party to a social contract as embodied in the constitution of our countries and in the government of the day. By far the majority of us conform to the rules and stipulations of that contract, on the one hand because of understanding the benefits that might flow from the contract in terms of personal and communal well-being, justice and fairness, rights and duties, and, on the other hand, out of fear of punishment and social sanction. There have been incidents, however, caused by pathological dissidents, such as Timothy McVeigh responsible for the Oklahoma Bombing and Anders Behring Breivik, responsible for the Norway massacre, who do not accept the authority vested in the government of the day on the basis of a social contract, and hence wish to opt out.

The academic exercise has the value, however, of revealing something of the dynamics of cultural and religious tolerance in our present-day diverse societies. It can arguably be expected that those individuals who operate with relatively minimalist values (Swartz 2006:551-570), with a totally relativistic value system, will more readily enter into a social contract because they do not feel very strongly about their own value system. For this group, values are 'just wonderful names with very little life and world view content', as Zecha (2007:48-60) has remarked. In terms of Bennett's (1993) developmental model, the members of this group arguably belong in either category IV - those who accept difference or category $\mathrm{V}$ - those who adapt to difference - or category VI - those who integrate difference (Bennett 1993:7-11). A person in this group might be prepared to practise cultural and religious pluralism and/or dialogical pluralism, and may also be tolerant of others and their cultural and religious views.

The obverse can also be expected. Those who operate with maximalist values (Swartz 2006:551-570) might be less willing to enter into a social contract because of their awareness of the deep value rifts that exist between themselves and others of different religious or cultural persuasion. The more maximalist their value system, the less likely they will be to enter into such a contract. There is also the distinct possibility that those operating with a maximalist value system that borders on fundamentalism and fanaticism, those with a 'toxic' cultural and religious orientation, might refuse to enter into a social contract. Such destabilising tactics can be observed both internationally where terrorist groups, inspired by religious fervour, attempt to undermine the extant world order (11 September 2001 is emblematic of this attitude), and nationally, where religious groups attempt to destabilise the national order of their country (Mali and the Democratic Republic of the Congo are at the time of publication suffering from such attempts). The members of these groups might also be intolerant of the cultural and religious views of other groups which they regard as cultural and political enemies and as heathens. In terms of Bennett's (1993) developmental model, this group might belong in category I - total denial of legitimate differences amongst people (totally exclusivist: only my culture and religion are true) or totally inclusivist (since only my culture and religion are true, I have to convert all others to it) - or category II - I have to defend myself against difference (Bennett 1993:1-3).

The person with a balanced value orientation might fall into Bennett's categories: 
III - I feel the need to minimize the differences between myself and others; the differences between myself and others are not all that important; we can talk about them and exchange ideas - dialogical pluralism

IV - acceptance of differences amongst people; people are different, and that is a fact of life, we have to live with it

$\mathrm{V}$ - adaptation to difference; although I have to live with the differences amongst people, I can be myself and apply my own value system in terms of the social contract to which I am party (Bennett 1993:3-7).

The person with a balanced value system will conditionally enter into a social contract with others and meet the responsibilities of doing so.

\section{Biblical perspective}

For the purposes of evaluating the South African social contract (see next section) and for gleaning certain pedagogical guidelines from the above and following discussions we would prefer to approach the problem from a biblical perspective. Space does not allow a detailed discussion of a biblical societal relationship theory which will describe all the structures, roles and responsibilities of all the societal relationships involved in a particular social contract. We can only pay attention to the societal relationship that is most pertinently involved in the social contract in a particular territory, namely the citizenry or civil society of an internationally recognised state, territory or region.

Analysis of the societal relationship ${ }^{3}$ that we refer to as the citizenry of a state reveals that it is historically founded in other words, it came into being as a result of historical circumstances and formative, creative decisions by politicians and other individuals of historical significance. As a result of their negotiations, decisions and power plays, a state with demarcated boundaries came into being, causing all those within those boundaries to become the citizens of that particular state. A citizen's presence within those boundaries causes him or her to become party to a social contract with all the other citizens within those boundaries. As a result of how the state historically came into being, they become subject to a certain set of rules, concretised in their country's constitution, legal system and social rules of conduct.

As a societal relationship, the citizenry has a dual destination or purpose: juridical and ethical. Its juridical purpose is to democratically elect a government, to subject itself to the constitution and the other laws promulgated by that government and to generally contribute to law and order, to be productive and responsible members of the state, to respect others and to look after their own and others' interests. Like all societal relationships, the citizenry of a country also has an ethical purpose. Mention has already been made of the fact that the citizens of a country should care for the interests of all other citizens, but the ethical purpose of a citizenry goes further than mere caring; a societal relationship is also perhaps mainly - founded on trust.

3.The following few paragraphs contain the authors' theory about civil society based on the societal relationship theory pioneered by H. Dooyeweerd, D.F.M. Strauss, P.G. Schoeman and others.
In an ideal world we could have expected the biblical norm of love of and service to one's neighbour to have been applicable. Not only should each citizen in such an ideal world love the triune God of the Bible with his or her whole heart (Mt 22:37-39; Mk 12:28-34), but also their fellow citizens as they love themselves (Mt 7:12; Rm 12:9-12; 2 Cor 1:1-3; 1 Pt 3:8-12). They should accept one another in love (Rm 15:7; Gl 5:13), act in the interests of one another ( $R m$ 15:2), bear one another's burdens (Gl 6:2), build one another by focusing on the others' strong points (Phlp 2-3), should conduct constructive communication (Eph 4:29), and generally make their love of others visible through their actions (1 Jn 4:12). The Bible abounds with 'one another' injunctions (love one another - Jn 15:17; show respect towards others - Rm 12:10; do not judge one another - Rm 14:15; instruct one another $\mathrm{Rm}$ 15:4, Cl 3:16; greet one another - $2 \mathrm{Cl}$ 13:12, to mention only a few). However, it would be unrealistic to expect the citizenry of a country to live in accordance with biblical rules and injunctions such as these because of the multicultural and multi-religious composition of the citizenries of the world. The best that can be hoped for is that the diverse populations of the various countries of the world should strive for peaceful coexistence (a peaceful modus vivendi) based on the ethical principles of trust and the Golden Rule.

According to Ariely (2010:127-128), the social contract amongst the citizens of a country is based on trust, which is why people get so upset when the contract is violated, and why they are willing to spend time and money on punishing the offenders. In saying this, he echoes a sentiment of Wright (2009:413) who avers that a modus vivendi is 'a problem of trust'. The smooth running of a society is sustainable in the long run only if there is a fair degree of trust within the citizenry, and between the government and the governed; trust frees a country of corruption and crime, the citizens are generally healthy and free of stress, and a sense of justice prevails at large. A good civil society, according to Ilbury and Sunter (2011:73), can be built only on the basis of the following four-way test: Is what is being said and done the truth? Is it fair to all concerned? Will it build goodwill and better relationships? Will it be beneficial to all concerned? All of these questions are an echo of Francis Fukuyama's (1996) thesis: each citizen of a country should be:

motivated by something broader than individual self-interest. ... in all successful economic societies these communities are united by trust (...) The ability to associate depends ... on the degree to which communities share norms and values and are able to subordinate individual interests to those of larger groups. Out of such shared values comes trust ... (pp. 9-11)

References to reciprocity, moral obligation, duty, caring about the interests of others and trust bring us to the second ethical principle, namely the Golden Rule as the basis of a social contract. Whereas the biblical Golden Rule of loving your neighbour as yourself (Mt 22:37-39; Mk 12: 28-34), but also your fellow citizens (Mt 7:12; Rm 12:9-12; 2 Cor 1:1-3; $1 \mathrm{Pt} 3: 8-12)$, would be paramount in a Christian society, it 
would be unreasonable - as observed above - to expect the same from secular-humanist societies, that is, societies not in any way bound by the principles of a particular religion or by the tenets of a particular religious organisation. ${ }^{4}$ Even in such secular societies, however, we find that the citizenry are being exhorted to subject themselves to some or other version of the Golden Rule. This ethical rule comes in many forms. Confucius (551 BC - 479 BC), for instance, said that the paramount virtue is ren (a sensitive concern for others), and he summarised this rule roughly as Hillel later would crystallise the Jewish Torah: 'Do not do to others what you would not wish for yourself' (Alford 2009:53; Wright 2009:237). Confucius also simply said: 'Love your fellow man'. Originally, this rule had only national application; only a generation later, the Chinese philosopher Mozi went further and explicitly advocated love of all humankind. Confucius also said: 'The wise man is attracted to benevolence (ren) because he finds it to his advantage' (see Wright 2009:237-238).

In India, Buddhist scripture had this to say: 'Let none cajole or flout / his fellow anywhere; / let none wish others harm / in dudgeon or in hate' (Wright 2009:237). Comte-Sponville (2005:7-8) presents this norm in different terms: 'You want to know whether an act is virtuous or reprehensible? Ask yourself what life would be like if everyone behaved as you do'. To be moral is to submit to a law which we all believe applies or should apply to all. This, he says, is the substance of the Kantian categorical imperative: 'Act only on that maxim by which you can at the same time will that it should become a universal rule'. According to Valenkamp (pers. comm... 08 March 2011), Kant's categorical imperative should not be confused with the Golden Rule of 'that which you do not wish to be done to you, do not do to others'. The Golden Rule is a hypothetical imperative since it does not strive at reaching a goal that is completely subjective, and focuses on the person who formulates that goal, namely the avoidance of things, events, circumstances and attitudes that one does not want to do. Kant aims at obligatory imperatives that fall outside the ambit of subjective will, opinion, feeling and loving. He therefore bases his view of morality and social justice in something that transcends the will; that is, beyond the wishes and desires of individuals and also beyond coincidence.

Kant's categorical imperative ties in with what Rousseau referred to as the 'sublime maxim': 'Do unto others as you would have them do unto you'. ${ }^{5}$ It also corresponds to the spirit of compassion formulated by Rousseau: 'Do good to yourself with as little possible harm to others'. This rule was later echoed in J.S. Mill's 'harm principle' (Morton 1998:170).

Ilbury and Sunter (2011:237) offer a more modern version of the rule, which they refer to in military terms as the 'rules

4.We find exceptions to this rule in certain Muslim countries, where the rules of a particular religion and of a particular religious organisation or system are also strictly applied in public life.

5.This same maxim appears in a mosaic in the building of the United Nations: 'As ye would that men should do to you do ye also to them likewise' (Clancy 1999:156). of engagement': normative rules are the moral rules of the game; they are one's conscience. They are the rules that, if adhered to, demonstrate a noble sense of purpose that everyone respects. Break them, and you lose the badge of honour in a second. The interesting thing about all these versions of the Golden Rule, according to Comte-Sponville (2005:7), is that the Rule applies only in the first person singular but it applies universally, in other words, to every human being (every human being is an ' $\mathrm{I}$ '). When an ' $\mathrm{I}$ ' acts, it is not only a matter of personal preference or individual taste; it is essentially a question of the survival of - and the dignity of - society as a whole, of humanity, of civilisation.

To return to the core of the argument: In a world governed by biblical principles one could have expected the social contract according to which the citizenry of a country conducted their lives and existence to have been guided by the biblical Golden Rule of loving the Lord, and all other people as much as the self. However, since we do not live in such a world and in fact have to conduct our existence in societies dominated by secular and humanistic values, we have to resort to the two ethical principles of trust and two rather more secular versions of the Golden Rule. When we now turn to an analysis of the South African secular-humanist ${ }^{6}$ social contract, we shall have to concentrate on these two aspects.

\section{The South African social contract}

Official South African documents embody a formulation of values: in the Constitution, the common law, a series of promulgated Bills, a Bill of Human Rights, manifestos and policies. They represent the absolute minimum value system that a group of people or a community such as a nation or a profession can live with without arguing too much about what they mean when formulating each value. In essence, they form the basis of a social contract since they express the general consensus and trust (Ariely 2010:127-128) that had been gained during negotiations. According to Smith and Oosthuizen (2011:7), it represents a vision, based on compromise, of the society that is worthy of the steadfast commitment of everyone. In the words of Currie and De Waal (2010:32), this commitment is an indirect application of values: the Bill of Rights establishes an 'objective normative value system', a set of values that must be respected whenever the common law or legislation is interpreted, developed or applied.

In many cases, it is up to legal authorities such as courts of law as protectors of the rights of citizens to interpret what exactly a certain value means in a certain society or in certain conditions (De Vos 2011; Schreiner 2005:6; Wright

6.The post-1994 South African social configuration can be regarded as secular since it is in no way connected to principles propounded by any particularist religion nor any church or any other religious institution. It is interesting to note that a former any church or any other religious institution. It is interesting to note that a former Minister of Education did not regard the South African situation as secular because, as he argued at the time, Government did not turn its back on religion or religious institutions but saw a place for it in civil life, particularly with respect to its policy on religion in education. In his own words: 'We do not have a state religion. But our country is not a secular state where there is a very strict separation between religion and the state' (Republic of South Africa 2003). Put differently, the South African government follows a cooperative model between state and religion/ religious organisations. 
2009:54-59). In this process, they contribute to the formulation of common law.

What, in a nutshell, is the content of the social contract that South Africans have agreed to in the past 20 years? In the first place, the Constitution (Act 108 of 1996, section 7 of the Bill of Rights, Republic of South Africa) entrenches the democratic rights of human dignity, equality and freedom. The pertinent affirmation of these three values makes them pivotal points of the Bill of Rights. From them flow the essential fundamental rights of equality, civilian freedom and human dignity. The value of human dignity in particular has often been affirmed by the High Court of South Africa to be the mother of all other rights, such as equality and non-discrimination. Section 10 of the Constitution also specifically affirms the value of the inherent human dignity of each and every citizen: each person is born as a human being, entitled to dignity that is equal to that of everybody else, irrespective of gender, creed, race, age, nationality, marital status, ethnicity, culture, language or religion. Non-respect for this value amounts to unfair discrimination, in contravention of section 9 of the Bill of Rights. Freedom has likewise been confirmed as a positive constitutional right: every person is free from all forms of violence, torture and insecurity and is entitled to freedom of religion, belief, thought, opinion, expression, association, movement, occupation or profession.

\section{Educating about the social contract}

It is clear from the above (South African) example that societies, as defined, tend to plan their structures and functioning on the basis of a social contract which embodies a number of core rights. The South African social contract entails agreements about a society based on the rule of law (the Constitution is the supreme law to which all behaviour and actions are subject), on the recognition of the fundamental and universally recognised rights of individuals (and via individuals or groups, including minorities), and on adherence to other laws, including those regarding education, in so far as they flow from and concur with the Constitution of the country.

The South African Ministry of Education (2001) realised that the basic tenets of the social contract, as outlined in the previous section, had to be taught to the learners in the schools, hence the publication of its Manifesto on democracy, values and education. A perusal of this Manifesto shows that the Ministry has selected ten core values with which learners should become intimately acquainted for South African society to move forward in a democratic, peaceful, dignified, trustful, respectful (loving) and prosperous manner. However, as we have also seen, this effort has so far not had the desired effect, hence the appeal to educators and educationists to make a renewed effort to acquaint, through education, the learners with the notion of the social contract that South Africans agreed to in the years 1994-1996, with the advent of the new democratic South Africa. The current amount of violence in the country attests to the distinct possibility that the 'free borns' (i.e. those born after 1994, who are now
18 or 19 years old) have not succeeded in fully grasping what the South African social contract entails, which seems to suggest that the Manifesto has so far not had the desired effect. To avoid producing yet another generation of 'free borns' ignorant of their social contract, school education in South Africa should now be purposely focused on bringing the implications of the South African social contract home to the children currently at school. Only through doing that will the current violence be curbed and hopefully eradicated. (The same applies to all other countries and societies where violence still is the order of the day.)

\section{Conclusion}

The fact of social disintegration in South Africa (and elsewhere) has forced us once again to look at the nature and contents of the social contract that the South African citizenry has entered into, voluntarily or not. In secular states, the social contract cannot be expected to be grounded in biblical ethical principles; it should, however, at the very least be rooted in two ethical principles that are widely recognised even in secular-humanist societies, namely trust and certain secular and humanistic versions of the Golden Rule. A positive modus vivendi could flow from the recognition and application of these two principles. The younger generations should be educated to understand all these principles: the nature and content of their social contract, the two ethical principles on which the social contract should ideally be based, and the need for a modus vivendi based on their particular social contract.

\section{Acknowledgements Competing interests}

The authors declare that they have no financial or personal relationship(s) that may have inappropriately influenced them in writing this article.

\section{Authors' contributions}

I.J.O. (North-West University) was specifically responsible for the section on the South African social contract. J.L.vd.W (North-West University) conceptualised the article and was responsible for the stylistic unity.

\section{References}

Alford, H., 2009, How to live. A search for wisdom from old people, Twelve Books, New York.

Ariely, D., 2010, The upside of irrationality, HarperCollins Publishers, New York.

Bennett, M.J., 1993, 'A developmental model of cultural sensitivity', Derived from: 'Towards a developmental model of intercultural sensitivity', in R. Michael Paige (ed.), Education for the intercultural experience, pp. 1-3, 7-11, Intercultural Press, Yarmouth.

Bower, C., 2005, Open minds, closed minds and Christianity, Aardvark Press, Valyland. Byerly, R.T., 2013, 'Business in society: The social contract revisited', Journal of Organisational Transformation and Change 10(1), 4-20. http://dx.doi.org/10.11 79/1477963312Z.0000000002

Clancy, T., 1999, State of siege, HarperCollins Publishers, London.

Columbia electronic encyclopaedia, 6th edn., p. 1, viewed n.d., from http://ehis. ebscohost.com.nwulib.nwu.ac.za/eds/detail?vid=2\&sid=ff47 cdb3-cbcc-4805 a1dd-275b74f29981\%40sessionmgr15\&hid=7\&bdata=JnNpdGU9ZWRzLWxpdm $\mathrm{U} \% 3 \mathrm{~d} \# \mathrm{db}=$ Ifh \&AN=39032855

Comte-Sponville, A., 2005, The little book of philosophy, Vintage/Random House, London. 
'Cops acquitted of Andries Tatane's murder', 2013, Mail \& Guardian, viewed 06 November 2013, from http://www.mg.co.za/article/2013-03-28-cops-acquittedof-andries-tatanes-murder

Currie, I. \& De Waal, J., 2010, The Bill of Rights handbook, Juta \& Company, Claremont.

De Botton, A., 2012, Religion for atheists, Hamish Hamilton, London.

De Vos, P., 2011, 'Freedom of religion: Not so free after all', Daily Maverick, 30 January, viewed 30 January 2013, from http://www.dailymaverick.co.za/opinionista/2012 09-11-freedom-of-religion-not-so-free-after-all/

Fukuyama, F., 1996, Trust: The social virtues and the creation of prosperity, Free Press Paperbacks, New York.

Ilbury, C. \& Sunter, C., 2011, The fox trilogy: Imagining the unimaginable and dealing with it, Human \& Rousseau/Tafelberg Publishers, Cape Town.

'Lonmin platinum mines in chaos: Special report Marikana', 2013, Mail \& Guardian, viewed 06 November 2013, from http://www.mg.co.za/report/lonmin-platinummines-in-chaos

McGrath, A., 2005, The twilight of atheism: The rise and fall of disbelief in the modern world, Rider, London.

Ministry of Education (South Africa), 2001, Manifesto on democracy, values and education, Ministry of Education, Pretoria.

Morton, A., 1998, Philosophy in practice, Blackwell Publishers, Malden.

Needleman, J., 2008, Why can't we be good?, Jeremy P. Tarcher/Penguin, New York.

Nussbaum, M.C., 2000, Women and human development: The capabilities approach, Cambridge University Press, Cambridge. http://dx.doi.org/10.1017/ CBO9780511841286

Olthuis, J.H., 2012, 'A vision of and for love: Towards a Christian post-postmodern worldview', Koers - Bulletin for Christian Scholarship 77(1), Art \#28, 7 pages. $\mathrm{http}: / /$ dx.doi.org/10.4102/koers.v77i.28

Parkin, J.C., 2011, $F^{* *} c k$ it: The ultimate spiritual way, Hay House, London.

Prasad, C., 2012, South African boers in Georgia?, European Centre for Minority Issues Working Paper \#55. January, 12 pages.

Rawls, J., 2007, 'A theory of justice', in H. LaFolette (ed.), Ethics in practice, pp. 565-577, Blackwell, Oxford.

Republic of South Africa, 1996, Constitution of the Republic of South Africa, Act 108 of 1996, Government Printer, Pretoria.
Republic of South Africa, 2003, National policy on religion and education, Ministry of Education, Pretoria.

Robeyns, I., 2005. 'The capability approach: A theoretical survey, Journal of Human Development and Capabilities 6(1), 93-117. http://dx.doi. org $/ 10.1080 / 146498805200034266$

Radiosondergrense (RSG), 2013, Radiobroadcast, 27 March.

Schreiner, P., 2005, Religious education in Europe, Comenius Institute, Oslo University Oslo, viewed 09 November 2012, from http://www.cimuenster.de/pdfs/themen/ europa2.pdf

Sen, A., 2010, The idea of justice, Penguin Books, London.

Smit, M.H. \& Oosthuizen, I.J. (eds.), 2011, Fundamentals of Human Rights and Democracy in Education - A South African perspective, COLMAR Publishers, Potchefstroom.

Strauss, D.F.M., 2009, Philosophy: Discipline of the disciplines, Paideia Press, Grand Rapids.

Swartz, S., 2006, 'A long walk to citizenship: Morality, justice and faith in the aftermath of apartheid', Journal of Moral Education 35(4), 551-570. http://dx.doi. org/10.1080/03057240601012287

'Taxi driver killed after alleged police brutality', Mail \& Guardian, viewed 06 November 2013, from http://www.mg.co.za/article/2013-02-28-taxi-driver-killed-afteralleged-police-brutality

The Citizen, 27 March 2013, pp. 6, 12-13

The Star, 27 March 2013, pp. 4-5, 8.

Van der Walt, B.J., 2007, Transforming power: Challenging contemporary secular society, Institute for Contemporary Christianity in Africa, Potchefstroom. PMCid:PMC1855345

Wilber, K., 2000, Sex, ecology, spirituality. The spirit of evolution, 2nd rev. edn., Shambalala Press, Boston \& London. PMCid:PMC1885698

Wright, A., 2010, 'Dancing in the fire: A deconstruction of Clive Erricker's postmodern spiritual pedagogy', Religious Education: The Official Journal of the Religion Education Association 96(1), 120-135. http://dx.doi.org/10.1080/00344080121331

Wright, R., 2009, The evolution of God, Little, Brown and Company, New York.

Zecha, G., 2007, 'Opening the road to values education', in D.N. Aspin \& J.D. Chapman (eds.), Values education and lifelong learning, pp. 48-60, Springer, Dordrecht. http://dx.doi.org/10.1007/978-1-4020-6184-4_2 